\title{
Entrevista \\ Mia Couto: garimpeiro da terra, das gentes, das palavras
}

\author{
Entrevista concedida a Jane Tutikian
}

Inegável é que hoje com mais de 20 obras publicadas entre textos de opinião, poemas, crônicas, contos e romances, Mia Couto é um dos grandes nomes da literatura africana e da literatura moçambicana. O escritor nascido em 1955 na cidade da Beira reafirma, a cada obra, o seu humanismo e a força de sua produção ficcional.

\section{PODE NÃO ESCREVER, MAS É POETA}

JT. Tu defines teu pai como um poeta, uma espécie de garimpeiro, olhando sempre para a terra. Quando ouvi isso, fiquei pensando que esta talvez tenha sido a tua grande herança, porque, no fundo, é o que és. Tu és uma espécie de garimpeiro que traz consigo uma linguagem poética muito forte...

MC. Provavelmente sim, seja esta a herança que recebi de meu pai. Não sei de outra coisa que não a poesia. Se sou alguma coisa, eu sou poeta. Se quero ser alguma coisa, eu quero ser poeta. E acho que essa lição o meu pai nos deu sendo ele mesmo. Ele não escrevia poesia. Ele era poeta mesmo. Naquilo o que era quase imperceptível, ele mostrava que havia qualquer coisa que era vital e que não estava ali de imediato, não estava ali à vista. Era qualquer coisa transcendente. Ele ensinou-nos a ver isto, além desse contato imediato.

JT. Ser poeta é uma forma de estar no mundo. Quem é poeta é poeta 24 horas por dia e não tem como fugir disso...

MC. Não, não há, porque é um olhar, seria preciso nascer outra vez, não depende de se fazer, o poeta pode não escrever, mas é poeta...

\section{A TERRA É UM PERSONAGEM QUE AJUDA A DESCOBRIR A MIM PRÓPRIO}

JT. Uma das coisas que me chama muito a atenção, ainda pensando no garimpeiro, é que teu olhar para a terra é muito forte, Moçambique está lá inteiro, se pegarmos o conjunto da tua obra, fica muito clara a questão da identidade. Se é verdade que todo o escritor tem o seu tema recorrente, a identidade é o teu tema recorrente?

MC. É o meu tema. Se há um assunto que eu posso dizer que é um processo forte dentro de mim é este. Para encontrar, para descobrir a minha identidade, eu vivi isso, no prin- 


\section{Conexão Letras}

cípio, como um drama, porque, sendo uma criatura de fronteira, estava ali entre dois mundos, África e Europa, o mundo da religiosidade pagã e o Cristianismo, o Oriente e o Ocidente... e portanto eu atravessei este momento em que parecia ter percebido uma identidade. Depois, percebi que isso era uma miragem e isto é o que eu quero dizer como - e isso não é nada filosófico - eu sou feliz porque aprendi a ser muitos a me distribuir e a viajar pelos personagens que crio. Eu sou aquela gente.

JT. Por outro lado, quando a gente pensa em independência, tanto a independência política quanto a econômica acontecem antes da cultural, te ouvindo, percebo que tu és um sujeito de fronteira num país que também está vivendo um momento fronteiriço de identidade cultural e isso termina repercutindo muito fortemente na tua obra. Existe um projeto de moçambicanidade realmente?

MC. Existe, sim. Ele não morreu. Eu sou muito feliz porque vivi nesse tempo em que comigo havia um país que estava fazendo um trabalho de ficção quase de invenção de si mesmo, de invenção de um país. É por isso que Moçambique está tão presente nos meus livros, ele é um personagem da minha história. Não é um cenário, a terra é um personagem, é alguma coisa que me ajuda a inventar a mim próprio.

\section{ESCREVO PARA MIM PRÓPRIO, PARA FANTASMAS QUE ESTÃO DENTRO DE MIM E PRECISAM SER ADORMECIDOS}

JT. Tu és um escritor absolutamente inquieto. Uma busca atravessa tua obra e te faz diferente daquele escritor definido pelo português Augusto Abelaira, que trazia consigo a sensação de estar sempre escrevendo o mesmo livro. Essa busca suscita uma pergunta imediata: para quem tu escreves?

MC. Olha, eu não sei para quem eu escrevo. Eu creio que escrevo para mim próprio, para fantasmas que estão dentro de mim e precisam ser adormecidos.

JT. E o que é ser um escritor, hoje, em Moçambique?

MC. Moçambique vive uma tentação enorme, a tentação da modernidade, isso foi o que nos fez caminhar ainda mais do que propriamente só a independência. A independência era vista como apenas uma parte dessa coisa de crescer do mundo, de crescer do tempo, de que gente era excluída e, então, a escrita tem um grande fascínio porque representa isso da modernidade em contraponto com a oralidade, com alguém que ainda não penetrou nesse universo da página. Provavelmente, isso ainda vai mudar mais um pouco com a introdução de outros meios como o computador, meios audiovisuais, mas eu acho que, por empréstimo disso, o escritor se beneficia de um prestígio enorme em Moçambique. Eu sou investido de um personagem que não sou. Na rua, as pessoas me param e me querem dizer coisas. Saio do aeroporto e ouço desde a pessoa que varre: você nos representa bem. Eu sinto, de repente, uma coisa que eu não quero ser, eu não quero ser um embaixador, eu não me sinto nenhum representante, represento-me só a mim e mal, mas sinto, ao mesmo tempo, que essa missão eu tenho que respeitar.

JT. A literatura, querendo ou não querendo tem este papel. E aquilo o que tu tens dentro de ti, essas vozes, às vezes terminam sendo, para o escritor, mais forte do que a realidade. 
MC. Não imaginas quanto. Eu falo isso com muita emoção. As pessoas querem me dar coisas. Numa das últimas viagens que eu fiz, alguém que eu não conhecia veio ter comigo e me disse, eu quero lhe dar uma palavra, eu pensei que ele queria trocar uma palavra comigo, mas ele insistiu que tinha uma palavra para me dar, que havia recolhido numa obra quando alguém disse que o trabalho era improvisório. E ele queria me dar esta palavra: improvisório. Isso me comove muito, porque é uma cumplicidade que se cria. Já não é o fã, já não é o admirador, é alguém que está fazendo conosco.

\section{O LIVRO QUE EU ME DEVIA}

JT. Qual o teu grande livro? Muito se fala de Terra Sonâmbula, até porque foi considerado um dos grandes livros africanos do Séc. XX...

MC. Terra Sonâmbula foi o único filho que me fez sofrer ao nascer. O resto foi sempre muito prazeroso. Mas aquele foi feito num momento muito atribulado, no meio da guerra. Eu pensava que nunca conseguiria fazer um livro sobre a guerra durante a guerra. Eu pensava que era preciso ficar em paz. Aquilo foi uma maneira de eu criar paz dentro de mim mesmo. Este livro marcou-me muito, muito. E só é possível explicar isso se eu disser que aquela guerra demorou muito tempo, demorou muita morte e estavam ali amigos meus, meus colegas tinham desaparecido e eu não tinha como resolver. Então, foi uma coisa meio delirante, sabes? A única vez que me aconteceu de eu quase chorar para não escrever mais e ser catapultado para o computador, portanto este livro marcou-me muito. Não quer dizer que eu ache que ele seja mais. Provavelmente um livro como o último romance que eu fiz, que aqui se chamou Antes de nascer o mundo, em Portugal se chamou Jesusalém e em França chama-se $O$ afinador de silêncio, (aqui tem o título que eu gosto mais, que eu acho que diz mais) tem uma estrutura narrativa mais conseguida, mas eu acho que sinto muita dificuldade em ser eu a falar sobre isso.

JT. Te ouvindo falar, eu fico pensando que existem alguns livros que o escritor deve a si próprio... talvez por isso todo o sofrimento

MC. Terra Sonâmbula eu me devia.

\section{O QUE A ÁFRICA PODE DIZER AO MUNDO: A RELIGIOSIDADE}

JT. Vamos falar um pouco de $O$ outro pé da Sereia. O foco continua sendo a questão identitária, mas tem um personagem que eu acho fascinante, o Lázaro, pela questão do encontro de culturas. Isso é Moçambique hoje?

MC. Eu acho que sim. É um encontro que nasce duma posição em que a pessoa não sabe quem é, se anula a si própria, acha que se tem que encontrar completamente nos outros, numa certa abdicação de si mesma, que nasce de uma sociedade colonizada, que criou a imagem do outro como aquele onde nós temos que chegar. Eu encontro isso um pouco no Brasil também.

JT. É, mas esse sujeito cindido entre a tradição e a modernidade é muito forte em Moçambique, porque- e aí eu acho a diferença com o Brasil - a tradição mítica é muito forte. 
MC. A diferença é que no Brasil não é dominante como é lá. É absolutamente dominante, quase exclusiva, esse é o mundo da pessoa. Agora, também é verdade que nós somos sempre de uma tradição, nunca somos uma coisa puramente moderna. Estive numa conferência sobre turismo, onde falava-se muito sobre as comunidades tradicionais. Eu também sou uma comunidade tradicional. O que eu acho que é anterior a isso, se calhar, e que é comum em relação ao Brasil, é o desejo de ser outro, de deixarmos de ser quem somos por instigação de um modelo. Eu vou falar sobre isso amanhã ou depois de amanhã. Eu estive em Natal, e havia um morro muito pobre, fronteira com a periferia e o que eu vi foram cartazes de pequenos negócios de salão de beleza e todos os cartazes tinham uma mulher loira de olhos azuis. Eu andei pela cidade e não vi nenhuma. Então é essa coisa do que é sonhado, do desejo de ser outro. É muito forte aqui também.

JT. É. Para nós, o modelo, no momento em que deixou de ser Europa, passou a ser EUA. Essa questão de uma hegemonia cultural fica camuflada - e eu acho que tu trazes isso de uma forma muito mais lúcida, muito mais clara no E se Obama fosse africano- no conceito de multiculturalismo. Fala-se em diálogo entre culturas, mas o exercício é monológico. Se houvesse um diálogo verdadeiro, o que a Africa poderia dizer, como contribuição, ao Ocidente?

MC. Uma coisa que eu acho que a África pode sugerir ao mundo é a maneira como cada um pode ser muitos e a habilidade de combinar filosofias, religiões dentro de cada um. Quer dizer, um africano pode ter duas religiões sem que isso implique desarmonia, e no meu país e nos países junto a Moçambique, que eu visitei, as pessoas são sempre duas coisas no território sagrado da religião. E essa habilidade de se distribuir entre o universo é muito necessária neste tempo da modernidade em que a gente tem que saber cruzar, tem que saber mestiçar-se. Esta habilidade os africanos podem dizer ao mundo: como é que fazem essa coisa que é uma sabedoria que, se calhar, eles não sabem como têm ou como se chega lá, mas há uma espécie de tranqüilidade numa religiosidade que é feita nas costas deste monoteísmo que me parece que não ajudou muito.

JT. Eu estava lembrando agora do Vinte e Zinco. O Ocidente tem medo desta religiosidade do africano. Na tua obra, o colonizador tinha medo daquilo o que ele não conseguia entender. É mais fácil olhar como alguma coisa misteriosa ou exótica...

MC. E tem a ver com mais outras coisas. Tem a ver com este drama de não sabermos resolver o assunto da eternidade, que é uma razão importante para aquilo que é a nossa própria felicidade. Como é que a Alice (personagem de Vinte e Zinco) resolveu aquilo tão bem, não é? Não existe essa apreciação do tempo linear em que há princípio e fim, portanto, os mortos não morrem, estão conosco. Quer morrer quem não é lembrado, não é quem deixou de viver. Isso funciona. Eu venho da Europa, eu tenho que me distribuir, eu tenho que pensar qual a verdade que me apetece mais, mas esta verdade apetece-me muito. Portanto, eu percebo como é que isso podia sarar alguma inquietação junto dos europeus, junto dos americanos. No fundo, buscamos muito isso. Não fomos feitos para ter fim, nascemos para viver sempre.

JT. Sobre a questão da religiosidade africana presente nos textos literários, eu já te ouvi dizer que o realismo mágico não serve, não diz o que é a Africa. Tu achas que tem que ser criado um novo conceito para isso ou o realismo animista sugerido pelo Pepetela é adequado? 
MC. Eu não queria dar nome a isso, para mim não é alguma coisa que tenha a ver com a apreciação da literatura, tem a ver com a apreciação do mundo. Eu nunca entenderia o Brasil se não soubesse nada sobre a religião católica. Mesmo que pessoalmente ou individualmente tu possas te afirmar ateu ou qualquer outra coisa, tudo se funda aí. Toda a marca de onde vens, toda a tua postura no mundo vem dali, então, se não se percebe essa religiosidade em África, não se consegue entendê-la e essa é uma questão anterior à literatura.

\section{FAZER NASCER O MUNDO IMPLICA SER-SE MULHER}

JT. Jesusalém tem muito do olhar feminino na recriação do mundo, mas A confissão da Leoa, que é um livro de situações extremas, se pensarmos na Maria Marta termina tratando, como o anterior, fortemente sobre a condição feminina. Eu gostaria de te ouvir sobre isso, porque a mulher também é tema recorrente teu.

MC. Para dizer a verdade, eu não sei mesmo responder... Provavelmente, para eu continuar essa busca dentro de mim daquilo o que são minhas identidades múltiplas, esse ser mulher é fundamental. Fundamental para eu olhar o mundo como se fosse uma coisa que ainda está a acontecer. Só me apetece, como se ela me sugerisse como se o mundo não está ainda feito e aquela história, digamos assim, representa essa coisa da consciência a partir do nada e é o que está também em Jesusalém e em A confissão da Leoa. Uma possibilidade de fazer nascer o mundo, de fazer tudo de novo, e isso implica ser-se mulher. Acho que é isso. Já que não se pode melhorar, é preciso nascer de novo.

\section{A LÍNGUA E O DEBATE PÓS-COLONIAL}

JT. E a questão da língua portuguesa? Em um dos teus textos de opinião afirmas que a língua portuguesa é um troféu de guerra, marca da soberania, a lusofonia, não...

MC. Isso implica um projeto que, eu tenho para mim, é um projeto de intenção política e que é uma espécie de viver num sentimento de império perdido, que é a idéia da lusofonia. Não sou militante desta causa, mas quero dizer que também não brigo contra ela. Entretanto, acho que é importante interrogarmos a razão dessa bandeira.

JT. E o troféu de guerra e a marca de soberania?

MC. Essa expressão fui roubar - até nem gosto muito que seja alguma coisa que tem que ser ligada à guerra - ao Corsino Fortes, poeta de Cabo Verde, que acho que foi o primeiro a referir-se à língua como qualquer coisa que foi conquistada. Eu acho que não é um troféu de guerra, é algum processo que foi ganho da História. Em Moçambique é muito curioso, porque é um processo cheio de ambivalências. A ata do Congresso da Frente de Libertação, que decide que a língua do futuro de Moçambique será a língua portuguesa, foi escrita em inglês, porque quem escreveu a ata não sabia português. O que tem que ser visível, aqui, é que esses países têm outras línguas e elas não podem ser relegadas a um plano tão secundário que, para ser membro desta família da lusofonia, a gente tenha que abdicar à nossa própria língua materna, nossa língua de expressão. É inevitável que a construção de uma nacionalidade ou de uma nação seja sempre fruto de violência, de 


\section{Conexão Letras}

outras guerras que não as feitas com bala. Essa violência vai marcar que o português seja hegemônico e que as outras línguas tenham um lugar muito alternativo e marginal.

JT. A literatura tem sempre mexido com as línguas locais, o que termina sendo uma espécie de afirmação de que esta é a nossa língua portuguesa, ou seja, marcada pelas línguas locais... Não é o teu caso, acho que tu tens uma característica diferente, que por exemplo, é diferente do Guimarães Rosa, que busca a linguagem regional, o Luandino, que trabalha com a linguagem dos musseques, o Honwana que envolve o ronga, tu és um esteta da palavra...

MC. Eu concordo contigo. Provavelmente havia no Honwana, no Luandino e quem sabe no Guimarães, um processo que não apenas os africanos tem, eles estão tão próximos desta luta de afirmação de uma identidade nacional, que estão a dizer: não é a nossa, mas também não é a deles. Eu acho que o meu trabalho é mais poético, pode ser que eu também queira dizer isso, mas não é isso o que me guia. O que me conduz é a poesia.

JT. Eu tenho ouvido com freqüência dos africanos que o pós-colonialismo não existe. No Vinte e Zinco, o próprio título, de certa forma diz isso..

MC. É isso. O outro vinte e cinco vai chegando sem essa proclamação espetacular de agora eu sou ou não sou e, provavelmente já está acontecendo há muito tempo, mas, de fato, eu acho que nós nos representamos, a nós próprios, ainda, como colonizados. Muito da maneira como Fanon olhava para o continente, quer dizer, o outro, essa representação do europeu, do colonizador está instalada na nossa cabeça e o que fazemos é muito em função dele. Uma das críticas que foi feita a mim, quando comecei a escrever desta maneira, foi: o que vão dizer os outros, que nós não sabemos escrever em Moçambique, que não sabemos escrever direito? Quer dizer, esta presença desta espécie de um grande pai ainda está ali como um fantasma, enquanto o que queremos é ser como eles . Vê a importância que atribuímos a isso. Acho que é uma coisa quase psiquiátrica, que leva um tempo de separação, é um processo. Mas eu acho que já acontece em África entre intelectuais que fazem filosofia, que apostam num pensamento próprio, original, que não quer ser sequer africano, que questiona este outro universo mental. Esse processo não é espontâneo. Ele tem que ocorrer e ser o resultado de alguém que, dentro da África, brigue com isso e faça nascer esse debate. 